\title{
The Economic Assessment of Conventional vs Gross Split Scheme for Anonymous Production Sharing Contract
}

\author{
Zilva Boaz
}

\begin{abstract}
The research is to perform economic assessment between conventional versus gross split scheme as mandated thru Regulation 52/2017 for Production Sharing Contract ("PSC") in Indonesia who is at the production stage; in this case Anonymous PSC. The objective is to give recommendations for Anonymous PSC to decide what concept will result the best outcome for Contractor. The research performed financial, SWOT analysis and 5 Forces of Porter. The simulation uses components of cost recovery, variable and progressive components to give pros and cons so that Anonymous PSC could consider whether it is economics to extend the business in Indonesia or not. Financial calculations are performed with assumptions should Contractors still implements the conventional or changes to gross split until the contract ends in 2028. The result using WACC $8.39 \%$ shows that both concepts are feasible. However, conventional scheme would be more beneficial for Contractor (oil project: IRR 19.1\%, NPV MMUSD 24.5; gas project: IRR 22.3\%, NPV MMUSD 297.5), since cost deduction performed after the sharing profit. Therefore, it is recommended to continue using conventional scheme until 2028. Extension will be considered by performing the economics $\&$ revisiting the contract.
\end{abstract}

Keywords - conventional, economics, gross split, production sharing contract, contractors cooperation contract.

\section{INTRODUCTION}

Oil \& gas plays an important role in every industry, thus, it is highly crucial for Government of Indonesia ("Gol") to protect their natural resources, oil \& gas in particular, in which it is guided under the Constitution of the Republic of Indonesia 1945 Art. 33 paragraph 1-3. In accordance to that, GoI released the Regulation number 44/1960 - that marked the Contract of Work ("CoW") which set the management concept of oil \& gas industry into the mineral \& mining (under GoI control \& supervision); and economic right (under Contractor's). Later on, GoI promulgated the Regulation number 8/1971 that acknowledged the Production Sharing Contract concept ("PSC"). The PSC has dynamically transformed from 1st to the 3rd generation of PSC in 1988 until now (applicable for the ongoing existing PSCs). However the production or profit sharing under the existing PSC is concerned to be changed where Ministry of Energy and Mineral Resources (“MEMR") released the Regulation 8/2017

Zilva Boaz is with the School of Business and Management, Institut Teknologi Bandung, Indonesia
- amended by Regulation 52/2017 on August 29, 2017; in regards with the Gross Split PSC. The intention is to optimize the efficiency and effectiveness of production or profit sharing of oil \& gas under PSC, by eliminating the cost recovery concept. The new scheme shall be applied for the new extension of PSC, while the ongoing PSCs can choose the conventional or change to gross split.

\section{Anonymous PSC Profile}

The Anonymous PSC covers a number of oil and gas fields in the Natuna Sea. Wise Company has been the operator (with $75 \%$ participating interest) of the offshore contract since 2016 which covers 11,155 square kilometers with water depths of 250-320 feet / 76.2-97.536 meter. Overall Wise now operates the facilities with 1 FPSO, 1 FSO, 4 central processing platforms, 7 wellhead platforms, 4 producing subsea fields, and offshore support vessels which support 3 producing oil fields and 16 natural gas fields in various stages of development. The oil has been produced since 1979, and peaked in the mid-1990s. Net daily production during 2015 averaged 5,000 barrels of liquids and $66 \mathrm{MMcf}$ of natural gas.

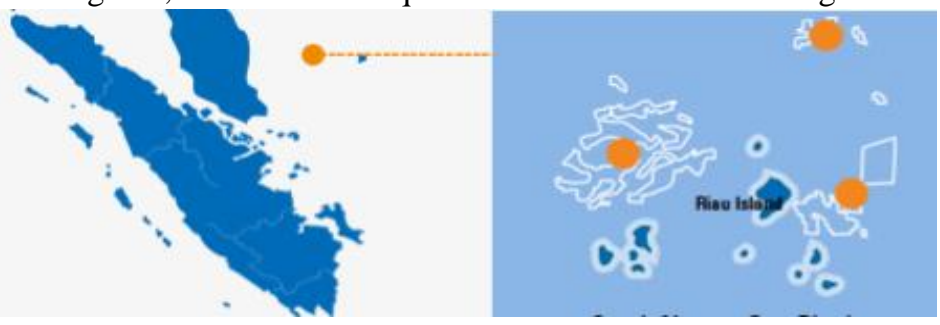

Fig. 1: Anonymous PSC working area

\section{Business issue}

Based on the report from Directorate General of Budget under Ministry of Finance (2015), that oil \& gas sector has been the major contribution where it had increasingly contributed from IDR184.6 trillion or almost 22\% (2009) to IDR320.3 trillion or $21 \%$ (2014) to the Government from the total revenue. However, oil \& gas sector declined in year 2015 to IDR63.7 trillion (YTD Q3) due to the decline of Indonesian Crude Price ("ICP") and production. Should they are still poor; the national income will follow their pattern. The production shortfall was due to the major oilfields in Indonesia has come under the mature category (95\%), as well as the lack of exploration activities. 


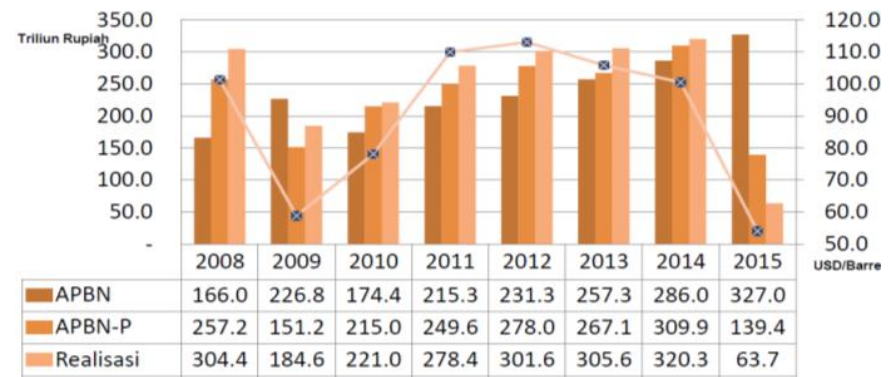

Fig. 2: National income from oil \& gas sector, source www.kemenkeu.go.id

The implementation of new scheme will impact to investors decision in oil \& gas sector, esp. in exploration phase with high investment, risk and uncertainty of proven oil \& gas. The existing PSCs will consider to extending the contract or not. Should they do not, the PSC termination will create less production and productivity, high unemployment as such. In the future, this sector will be no longer a major contribution for the national revenue. Gross Split regulation becomes a major concern for the investors and gives significant impact to the contribution of economy and development growth. Several research questions to be assessed are:

1. What are the pros \& cons of conventional and gross split scheme implementation for Contractor?

2. What are the financial outcomes from both schemes for Anonymous PSC - the Contractor side?

3. Which scheme will perform the most profitable outcome for Anonymous PSC - the Contractor?

\section{Objective}

The research's objective is to perform the economic assessment thru business valuation on Anonymous PSC by comparing the PSC scheme between conventional and gross split in generating the pros \& cons as well as the financial outcomes as recommendations for Anonymous PSC.

\section{A. Business Issue Exploration}

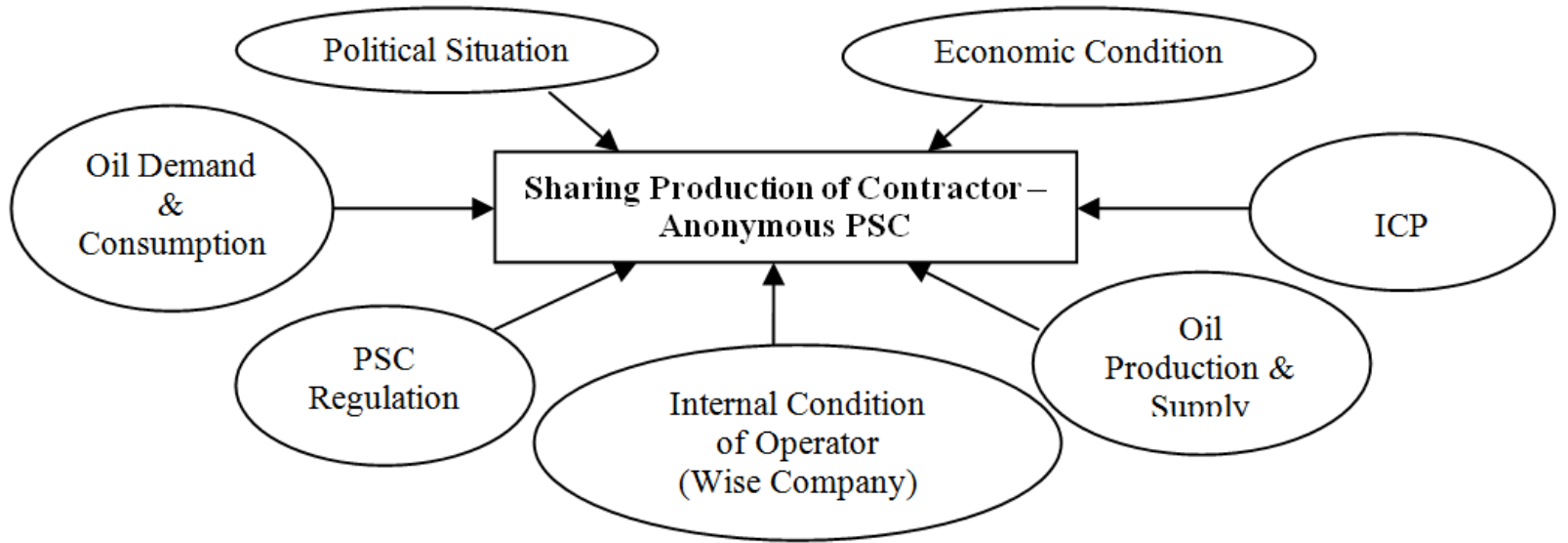

Fig. 3: Conceptual framework

TABLE I:

SHARING PRODUCTION PERCENTAGE OF ANONYMOUS PSC

\section{Macro Analysis}

\section{- Political situation}

The national political situation truly influences the oil \& gas business sector.

\section{- Economic Condition}

All PSCs are targeted by the Government to contribute to the national revenue. Specific targets underlined on the State Budget which is translated under approved annual WP\&B by SKKMIGAS.

\section{Micro Analysis}

\section{- PSC regulation}

PSC agreement will determine the percentage of sharing production or profit between GoI and Contractor. Below is the sharing percentage between conventional and gross split scheme:

\begin{tabular}{|c|c|c|c|c|}
\multirow{2}{*}{ Product } & \multicolumn{2}{|c|}{ Sharing Production Percentage of Anonymous PSC } \\
\cline { 2 - 5 } & \multicolumn{2}{|c|}{ Conventional } & \multicolumn{2}{|c|}{ Gross Split* } \\
\cline { 2 - 5 } & GoI & Contractor & GoI & Contractor \\
\hline OIL & $71.1538 \%$ & $28.8462 \%$ & $57 \%$ & $43 \%$ \\
\hline GAS & $32.6923 \%$ & $67.3077 \%$ & $52 \%$ & $48 \%$ \\
\hline
\end{tabular}

- ICP

The higher the ICP rate, the higher the gross production. As the gross production generates the gross sales, thus the more the gross production/sales will generate more sharing production/profit.

\section{- Oil production \& supply}

The supply has negative correlation with the oil price. The high the supply, the low price will be, and the other way around.

\section{- Oil demand \& consumption}

The high the demand, the high price will be, and the other way around. In conclusion, the oil demand has positive correlation with the sharing production/profit of Contractor.

\section{- Internal condition of Wise Company}

The SWOT Analysis of Wise is elaborated as follows: 
TABLE II:

SWOT ANALYSIS ON WISE COMPANY

\begin{tabular}{|l|}
\hline Strength \\
\hline - Operator of Anonymous PSC \\
- Production phase \\
- High daily capacity of 19,279 bpod of oil \& \\
condensate, and 195.7 mcf of natural gas (2016) \\
- PSC Expiry date in 2028 \\
- High skilled national resources \& experts, good brand image \\
\hline Opportunity \\
\hline - Gross Split scheme to apply once the PSC has expired \\
- Economic condition in Indonesia to support the investment \\
opportunity \\
- High sharing percentage, production and profit for implementing Cost \\
Recovery PSC \\
\hline
\end{tabular}

\section{B. Five Forces of Porter Analysis}

The elaboration 5 Porter Analysis for Anonymous PSC can be described as follows:

- The treat of new entrants (Low): Since industry demands high investment (technology and capital) and high risk as well.

- The power of suppliers (Low): The Indonesian oil sector with reference to the power of suppliers follows the general trend present in the oil and gas industry: a balanced relation between suppliers and oil companies. The suppliers however do not have many alternative buyers.

- The power of buyers (Direct Buyers Medium - Final Buyers Low): The individual purchaser of refined products has low bargaining powers.

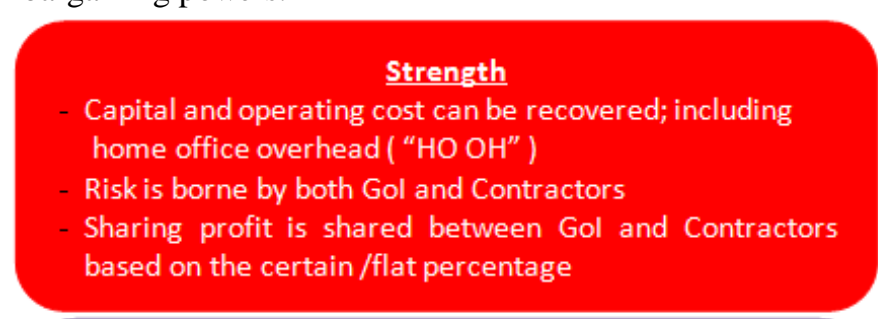

\section{Opportunity}

Certain and clear target is specified, discussed and

agreed by both Gol and Contractors

More control and supervision from the Government

\section{Weakness}

- High investment on the technology and human resources

- High risk should the reserves are not proven

- Other PSCs are on the exploration phase which require more capital injection

- Future market size

\section{Threat}

- ICP fluctuation

- Political situation in Indonesia (upcoming national election in 2019)

Non cost recovery $=$ high sunk cost Strict government regulation for the procurement/tender, projects, etc.

- The threat of substitutes (Low/Medium): In the future the needs for the alternative will be high especially renewable ones (geothermal, etc). However, currently they are limited and not sufficient to fulfill market needs.

- Rivalry among the existing competitors (High): Following considerations: 1) Many competitors (263 PSCs on March 2017); 2) Industry growth is slow (esp. in 2013/2014 due to the decline of ICP); 3) High exit barriers; 4) Rivals; esp. from the international major oil \& gas companies with high commitment to the business well managed, already engaged with the buyers for long term contract.

\section{C.SWOT Analysis}

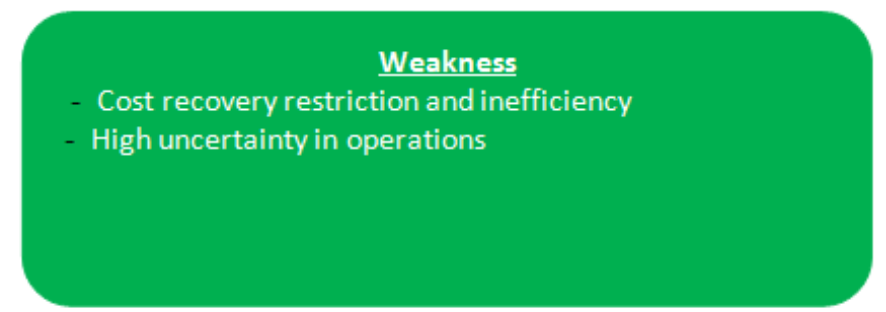

Threat

Strict Government audits - BPKP, Tax Office, SKK

MIGAS

Long approval and bureaucracy for projects (POD, PSC

extension, AFE submission, WP\&B, AFE closed out, cost

recovery, etc.)

Delay in permit, delay in project

Complex reports to Government

Fig. 4: Conventional PSC SWOT analysis 

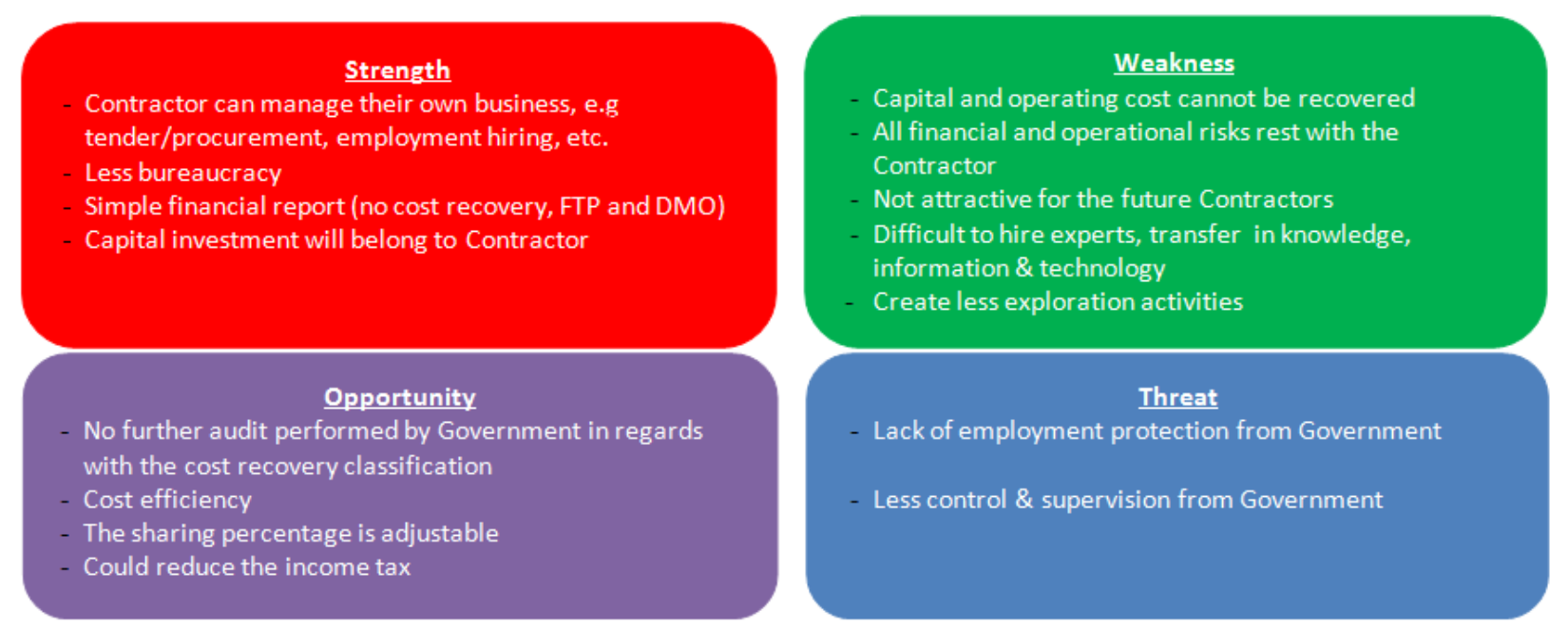

Fig. 5: Gross split PSC SWOT analysis

D. Financial simulations between Conventional vs Gross Split PSC at Anonymous PSC

The flow of sharing production or profit of Anonymous PSC
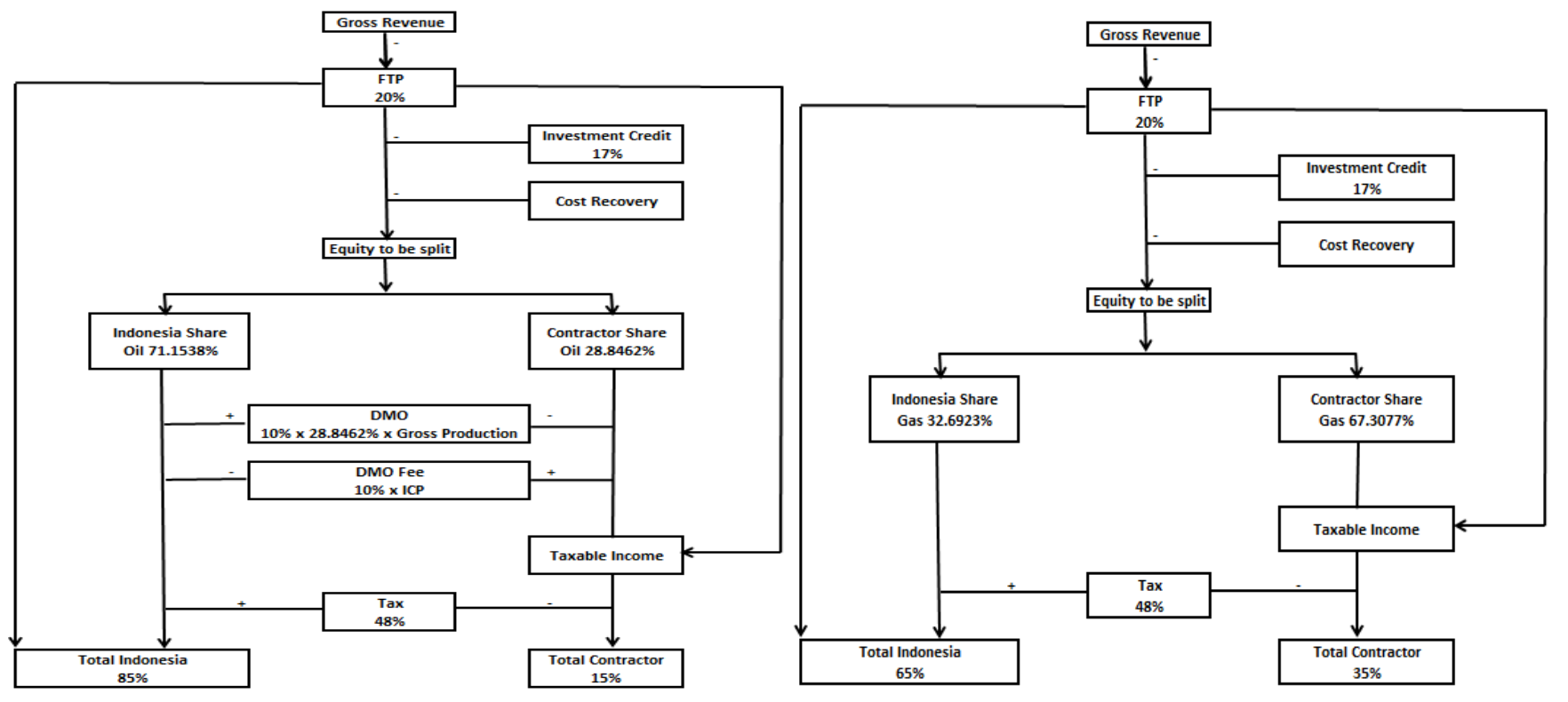

Fig. 6: Oil and gas sharing production/profit for Anonymous PSC - conventional

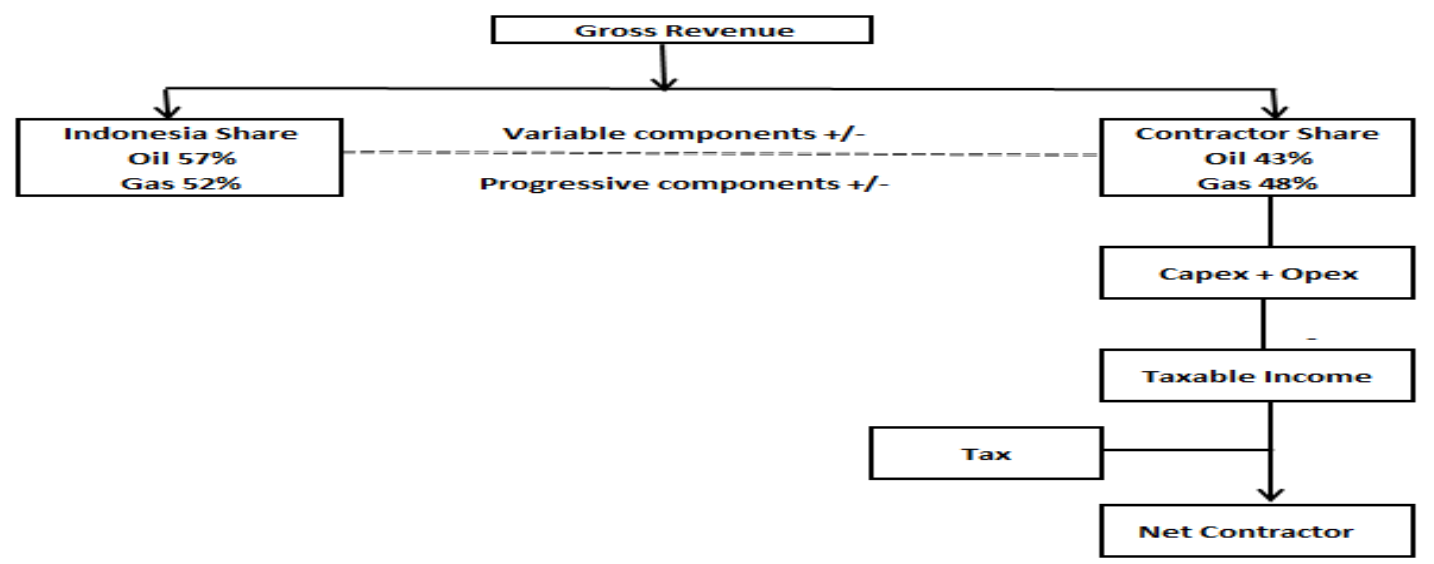

Fig. 7: Sharing production/profit for Anonymous PSC - gross split 
For Anonymous PSC, the gross split components can be determined as follows (applicable for year 2017, while the following year will be adjusted based on the changes of each component, if any):

TABLE III:

VARIABLE AND PROGRESSIVE COMPONENTS OF ANONYMOUS PSC

\begin{tabular}{|c|l|l|c|}
\hline No & \multicolumn{1}{|c|}{ Variable Components } & \multicolumn{1}{|c|}{ Observations } & Split Adjustment (\%) \\
\hline 1 & POD status & No POD amendment & 0 \\
\hline 2 & Field location & Offshore $(76.2-97.536$ meter) & 12 \\
\hline 3 & Reservoir depth & $<=2500$ & 0 \\
\hline 4 & Infrastructure availability & Well developed & 0 \\
\hline 5 & Reservoir type & Conventional & 0 \\
\hline 6 & Carbon dioxide content & $5<=\mathrm{x}<10$ & 0.5 \\
\hline 7 & Hydrogen sulfide content & $<100$ & 0 \\
\hline 8 & Oil specific gravity & $>=25$ & 1 \\
\hline 9 & $\begin{array}{l}\text { Domestic component level on the development field } \\
\text { phase }\end{array}$ & $30 \%<=\mathrm{x}<50 \%$ & 2 \\
\hline 10 & Production phase & Secondary & 6 \\
\hline No & \multicolumn{1}{c|}{ Observations } & Split Adjustment $(\%)$ \\
\hline 1 & Oil price & US\$ 48/Bbl (2017 revised WP\&B) & 9.25 \\
\hline 2 & Natural gas production & US\$ 7/MMBTU & 0 \\
\hline 3 & Oil \& gas cumulative production & $>=175$ MMBOE & 0 \\
\hline
\end{tabular}

It generates the sharing percentage between GoI and Contractor as follows.

TABLE IV:

SIMULATION BETWEEN CONVENTIONAL VS GROSS SPLIT PSC (VARIABLE \& PROGRESSIVE COMPONENTS)

\begin{tabular}{|l|c|c|c|c|}
\hline \multirow{2}{*}{$\begin{array}{c}\text { Sharing Production Percentage - } \\
\text { Anonymous PSC }\end{array}$} & \multicolumn{2}{|c|}{ Crude Oil } & \multicolumn{2}{|c|}{ Natural Gas } \\
\cline { 2 - 5 } & $\begin{array}{c}\text { Existing PSC } \\
\text { (Cost Recovery) }\end{array}$ & $\begin{array}{c}\text { Gross Split } \\
\text { PSC }\end{array}$ & $\begin{array}{c}\text { Existing PSC } \\
\text { (Cost Recovery) }\end{array}$ & $\begin{array}{c}\text { Gross Split } \\
\text { PSC }\end{array}$ \\
\hline Government & $71.1538 \%$ & $27 \%$ & $32.6923 \%$ & $36 \%$ \\
\hline Contractor & $28.8462 \%$ & $73 \%$ & $67.3077 \%$ & $64 \%$ \\
\hline
\end{tabular}

\section{- Financial simulation using NPV and IRR}

The discount rate is calculated using formula of Weighted Average Cost of Capital ("WACC")

$$
W A C C=K_{e} \times W_{e}+K_{d} \times(1-T) \times W_{d}
$$

The calculation of Cost of Equity (Ke) is performed using Capital Asset Pricing Model ("CAPM") which consists of Risk-Free Rate of Return (Rf) using 2017 SBI rate of $5.90 \%$. To determine the risk premium (Expected Return of the Market "Rm" - Rf) using Damodaran analysis from NYU
Stern; which is $8.82 \%$ for Indonesia while Beta of Asset (B) us from infinancials.com is 1.20 .

$$
\begin{aligned}
& K e=R f+\beta *(R m-R f) \\
& K e=5.90 \%+1.20(8.82 \%) \\
& K e=16.48 \%
\end{aligned}
$$

The calculation of Cost of Debt $(\mathrm{Kd})$ is based on the market value of Company's debt, weighted rate to the total debt, local currency depreciation to USD as well as interest rate of each debts. Thus, the depreciation would be $3.25 \%$, forward currency IDR 13,763 and Kd of Wise Company $8.76 \%$.

TABLE V:

COST OF DEBT AND WACC OF WiSE COMPANY, SOURCE: WisE COMPANY In USD

\begin{tabular}{|l|r|r|r|r|}
\hline & \multicolumn{1}{|c|}{ Rate } & \multicolumn{1}{|c|}{ Total Debt } & Weighted & Weighted Rate \\
\cline { 2 - 5 } BANK LOANS & & & & \\
- Bank I & $5,00 \%$ & 140.000 .000 & $15,14 \%$ & $0,76 \%$ \\
- Bank II & $5,00 \%$ & 180.925 .000 & $19,56 \%$ & $0,98 \%$ \\
- Bank III & $5,00 \%$ & 16.000 .000 & $1,73 \%$ & $0,09 \%$ \\
& & & & \\
BONDS & & & & \\
Dollar & $6,05 \%$ & 17.849 .627 & $1,93 \%$ & $0,12 \%$ \\
Rupiah & $11,80 \%$ & 498.779 .232 & $53,94 \%$ & $6,36 \%$ \\
SGD & $5,90 \%$ & 71.198 .859 & $7,70 \%$ & $0,45 \%$ \\
\hline TOTAL & & 924.752 .718 & $100,00 \%$ & $8,76 \%$ \\
\hline
\end{tabular}

\begin{tabular}{|l|r|}
\hline US interest rate & $1,25 \%$ \\
\hline Indonesia interest rate & $4,50 \%$ \\
\hline Currency depreciation - Rupiah to Dollar & $3,25 \%$ \\
\hline UUSD to Rupiah & 13.330 \\
\hline Forward Currency & 13.763 \\
\hline
\end{tabular}

\begin{tabular}{|l|r|}
\hline Cost of Equity & $16,48 \%$ \\
\hline Cost of Debt & $8,76 \%$ \\
\hline Debt Ratio & $81,6 \%$ \\
\hline Equity Ratio & $18,4 \%$ \\
\hline Tax & $25 \%$ \\
\hline WACC & $\mathbf{8 . 3 9 \%}$ \\
\hline
\end{tabular}

\section{BUSINESS SOLUTION}

Having elaborated both schemes using SWOT Analysis, the pros \& cons from each scheme as follows: 
TABLE VI:

CONVENTIONAL PSC PROS AND CONS

\begin{tabular}{|ll|l|}
\hline \multicolumn{1}{|c|}{ Pros } & \multicolumn{1}{|c|}{ Cons } \\
\hline 1. & \multicolumn{1}{|c|}{ Capital and operating cost can be recovered } & 1. Long approval and bureaucracy for the projects \\
2. Risk both financial and operation are borne by both GoI and & 2. Delay in permit, delay in project, less economics \\
& 3. Strict government audit in regards with cost recovery \\
3. $\begin{array}{l}\text { Sharing profit is shared between GoI and Contractor with certain } \\
\text { percentage as stipulated on the PSC Agreement }\end{array}$ & 4. Complex reports to Government \\
4. More control \& supervision by the Government & \\
\hline
\end{tabular}

TABLE VII:

GROSS SPLIT PSC PROS AND CONS

\begin{tabular}{|cl|l|}
\hline \multicolumn{1}{|c|}{ Pros } & \multicolumn{1}{|c|}{ Cons } \\
\hline 1. & Contractor could manage their own business & 1. Capital and operating cost cannot be recovered \\
2. Less bureaucracy & 2. Risk both financial and operational are borne by Contractor only \\
3. & Capital investment belongs to Contractor & 3. Create less exploration activities \\
4. Simple financial and other reports & 4. Difficulty in transfer knowledge and technology \\
5. & Cost efficiency & \\
\hline
\end{tabular}

Both schemes truly perform their own pros and cons in a

cons of the concepts are defined: different way. In summary, the direct comparison of pros \&

TABLE VIII:

LIST PROS AND CONS BETWEEN CONVENTIONAL VS GROSS SPLIT PSC

\begin{tabular}{|l|c|c|}
\hline \multicolumn{1}{|c|}{ Item } & Conventional PSC & Gross Split PSC \\
\hline 1. Cost Recovery & $\sqrt{ }$ & - \\
\hline 2. Sharing risk & $\sqrt{ }$ & - \\
\hline 3. Less bureaucracy & - & $\sqrt{ }$ \\
\hline 4. Cost efficiency & - & $\sqrt{ }$ \\
\hline 5. Capital investment ownership & - & $\sqrt{ }$ \\
\hline 6. More control and supervision from government & $\sqrt{ }$ & - \\
\hline 7. Exploration activities & $\sqrt{ }$ & - \\
\hline 8. More potential productions & $\sqrt{ }$ & - \\
\hline 9. Transfer knowledge and advanced technology & $\sqrt{ }$ \\
\hline 10. Less complexity in government audits and regulations & - & $\sqrt{ }$ \\
\hline 11. Contractor authority to manage the business & - & $\sqrt{ }$ \\
\hline 12. Simple financial and other reports to government & - & - \\
\hline 13. Home office overhead is subject to cost recovery & $\sqrt{ }$ \\
\hline
\end{tabular}

The table above shows less risk and a bit effort should Contractor using the conventional scheme. While in contrary, using the gross split PSC will create less effort but high risk for the Contractor. The alternatives given will be further analyzed to determine the implications.

\section{A. Financial Outcome between Conventional Vs Gross Split PSC}

The projections of cost and production both oil \& gas in Anonymous PSC are shown below:

TABLE IX:

COST AND PRODUCTION PROJECTION - OIL AND GAS

\begin{tabular}{|c|c|c|c|c|c|c|c|c|c|}
\hline \multirow{2}{*}{ Year } & \multicolumn{2}{|c|}{ Investment (MMUSS) } & \multirow{2}{*}{$\begin{array}{c}\text { Opex } \\
\text { Uss/Bbl }\end{array}$} & \multirow{2}{*}{$\begin{array}{c}\text { Production } \\
\text { mbblpd }\end{array}$} & \multirow{2}{*}{ Year } & \multicolumn{2}{|c|}{ Investment (MMUSS) } & \multirow{2}{*}{$\begin{array}{c}\text { Opex } \\
\text { USS/MCF }\end{array}$} & \multirow{2}{*}{$\begin{array}{l}\text { Production } \\
\text { MMSCFD }\end{array}$} \\
\hline & Capital & Non Capital & & & & Capital & Non Capital & & \\
\hline o & - & 65 & & & 0 & of & 339 & & \\
\hline 1 & 11 & 21 & 9 & 19 & 1 & 55 & 105 & 0,45 & 178 \\
\hline 2 & 19 & 23 & 9 & 20 & 2 & 96 & 113 & 0,45 & 154 \\
\hline 3 & 32 & 21 & 9 & 23 & 3 & 158 & 104 & 0,45 & 175 \\
\hline 4 & 30 & 20 & 9 & 20 & 4 & 152 & 99 & 0,45 & 187 \\
\hline 5 & 38 & 19 & 9 & 14 & 5 & 153 & 74 & 0,45 & 134 \\
\hline 6 & 26 & 18 & 9 & 10 & 6 & 104 & 70 & 0,45 & 124 \\
\hline 7 & 23 & 9 & 9 & 9 & 7 & 182 & 74 & 0,45 & 161 \\
\hline 8 & 10 & 8 & 9 & 5 & 8 & 84 & 65 & 0,45 & 213 \\
\hline 9 & 7 & 7 & 9 & 3 & 9 & 57 & 56 & 0,45 & 180 \\
\hline 10 & - & - & 9 & 3 & 10 & o & of & 0,45 & 150 \\
\hline 11 & - & - & 9 & 3 & 11 & 의 & of & 0,45 & 136 \\
\hline 12 & - & - & 9 & 3 & 12 & of & 0 & 0,45 & 126 \\
\hline Total & 197 & 209 & & 133 & Total & 1.040 & 1.097 & & 1.918 \\
\hline
\end{tabular}

Based on the data and tables given, the economics calculation of Anonymous PSC with financial outcome of
NPV and IRR Contactors would result as follows: 
TABLE X:

FINANCIAL OUTCOME OF ANONYMOUS PSC USING CONVENTIONAL VS GROSS SPLIT PSC

\begin{tabular}{|c|c|c|c|c|c|}
\hline \multirow{2}{*}{ Indicator } & & \multicolumn{2}{|c|}{ Conventional PSC } & \multicolumn{2}{|c|}{ Gross Split PSC } \\
\hline & & Oil & Gas & Oil & Gas \\
\hline IRR Contractor & 96 & $19,1 \%$ & 22,396 & 17,896 & 11,996 \\
\hline Total Contractor & 96 & 15,096 & 35,096 & 43,096 & 48,096 \\
\hline Contractor NPV & mmiss & 24,5 & 297,5 & 12,2 & 80,5 \\
\hline Contractor Total Take & mmuss & $1.696,3$ & $3.189,6$ & $1.767,8$ & $3.580,6$ \\
\hline Contractor Net Share & mmuss & 129,5 & $1.076,7$ & 104,5 & 763,2 \\
\hline Government NPV & mmuss & 535,3 & $1.172,9$ & 471,7 & $1.007,2$ \\
\hline Government Total Take & minuss & 733,9 & $1.999,6$ & 662,4 & $1.608,7$ \\
\hline
\end{tabular}

The table above shows the consistent results; that overall (cumulative of oil \& gas product) for conventional scheme result the greater sharing profit in IRR, NPV and net share for both oil \& gas to Contractor compare to gross split scheme. Should the situation is aligned with projection, it will be more profitable in oil project for Contractor using conventional scheme than gross split scheme. In gas project, both concepts are profitable as they generate high and positive NPV. Taking conventional concept will be more profitable after all. In addition, there are several factors that influence those financial outcomes which are oil \& gas production, oil \& gas price, sharing percentage and tax.

\section{B. Analysis of Business Solution Alternative}

To ensure the alternative chosen is the best, the research also performs the Kepner-Tregoe approach:

TABLE XI:

DECISION ANALYSIS OF CONVENTION VS GROSS SPLIT

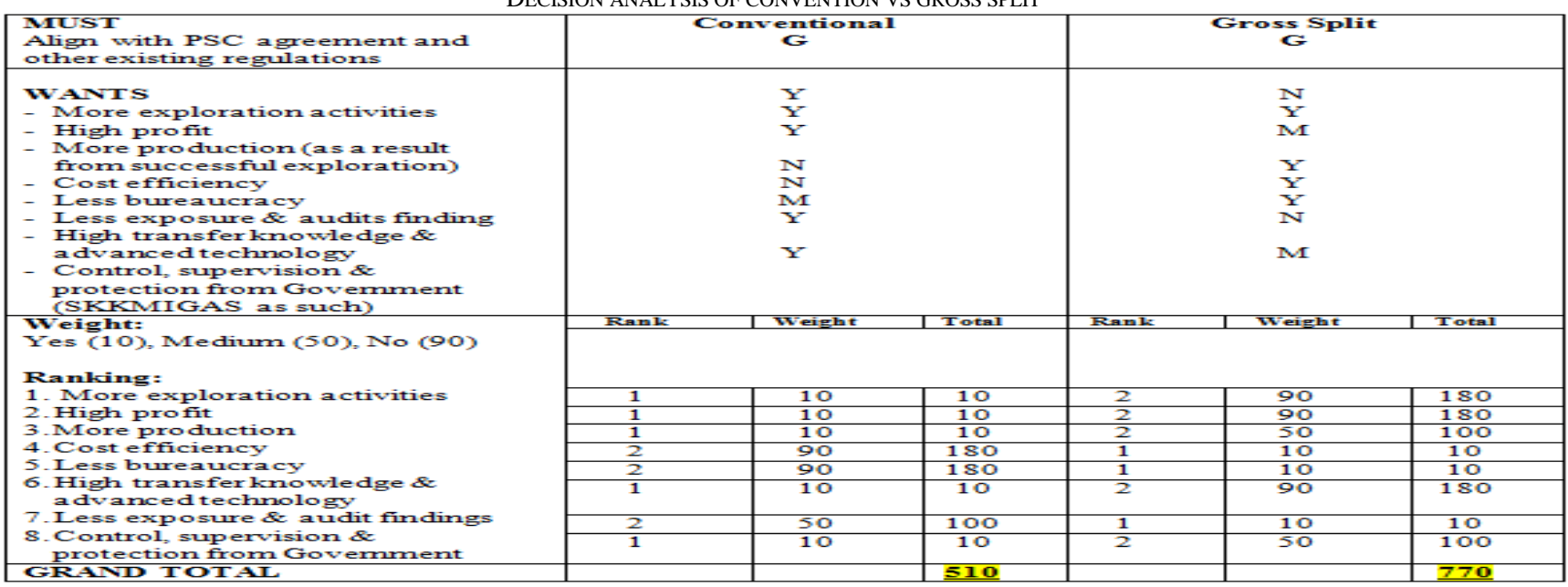

Note: Go (G), Not Go (NG), Yes (Y), Medium (M), and No (N)

Based on the approach, basically both schemes fulfill the "must-have" attribute in which the concepts do not conflict with the regulation. The result shows that conventional scheme generates less score (510) compared to gross split (770), thus it indicates that the conventional PSC could be considered and recommended as the most optimum solution than the gross split (with regards to the condition and circumstances of the
Anonymous PSC and oil \& gas industry).

In conclusion, the research recommends that Wise Company to use the conventional scheme until 2028. The future event or potential problem implications as anticipations from the implemented concept shall be taken in to attention for Anonymous PSC as follows:

TABLE XII:

\begin{tabular}{|c|c|c|}
\hline Future Event & Consequences & Probable Causes \\
\hline $\begin{array}{l}\text { Keep using conventional PSC scheme } \\
\text { until expiry date in } 2028 \text {. }\end{array}$ & \multirow[t]{2}{*}{$\begin{array}{l}\text { - High bureaucracy. } \\
\text { - Less cost efficiency. } \\
\text { - High exposure \& audit } \\
\text { findings. } \\
\text { ions }\end{array}$} & $\begin{array}{l}\text { - Long approval \& bureaucracy for the projects. } \\
\text { - Delay in permit \& project, less economics. } \\
\text { - Strict government audit in regards with cost recovery. }\end{array}$ \\
\hline Preventive Actions & & Contingent Actions \\
\hline \multicolumn{2}{|c|}{$\begin{array}{l}\text { - Professional approaches with the Regulator/ } \\
\text { Authority by maintaining good relationship with them, attending } \\
\text { invitation of external meetings and regulation socialization, being } \\
\text { cooperative and responsive, participating in the events, submitting the } \\
\text { requests (reports, documents) in time, and so on. } \\
\text { - Comply with the procedures \& regulations: } \\
\text { - Internal procedures } \\
\text { - Government regulations }\end{array}$} & $\begin{array}{l}\text { To deal with high bureaucracy, exposure \& audit findings: } \\
\text { - Conduct peer audit across function. } \\
\text { - Perform internal audit in regular } \\
\text { To deal with less cost efficiency: } \\
\text { - Restructure the effective organization, less hierarchy, utilize and } \\
\text { empower the existing human resources. } \\
\text { - Reduce the overhead cost }\end{array}$ \\
\hline
\end{tabular}


In the future, Contractor could later on consider to extend the contract or not by revisiting the term and condition of the new contract with Government as well as performing the economics simulation since the regulation shall be dynamic over the time.

\section{ACKNOWLEDGEMENTS}

The author would like to acknowledge the friends and family who supports throughout the completion of the journal.

\section{REFERENCES}

[1] Direktorat Penyusunan APBN, Direktorat Jendral Anggaran. 2017. Informasi APBN 2017. APBN yang lebih kredibel dan berkualitas di tengah ketidakpastian global. Kementrian Keuangan

[2] Kementrian Energi dan Sumber Daya Mineral Republik Indonesia. 2017. Peraturan Menteri Energi dan Sumber Daya Mineral Republik Indonesia Nomor 52 Tahun 2017 Tentang Perubahan atas Peraturan Menteri Energi dan Sumber Daya Mineral Republik Indonesia Nomor 08 Tahun 2017 Tentang Kontrak Bagi Hasil Gross Split. Departemen Energi dan Sumber Daya Mineral.

[3] Petromindo, "Indonesian Oil \& Gas Book 2008", Petromindo, 2008.

[4] Priamoko, Nugroho Eko, "Catatan Seputar Kontrak Bagi Hasil Gross Split, 2017.

[5] PwC Indonesia, "Indonesia Energy, Utilities \& Mining NewsFlash/February 2017/No 60: Special Edition - Gross Split PSCs", PwC, 2017. 